\title{
Acaconin, a chitinase-like antifungal protein with cytotoxic and anti-HIV-1 reverse transcriptase activities from Acacia confusa seeds
}

\author{
Sze Kwan Lam ${ }^{\bowtie}$ and Tzi Bun $\mathrm{Ng}^{\varpi}$ \\ School of Biomedical Sciences, Faculty of Medicine, The Chinese University of Hong Kong, Shatin, New Territories, Hong Kong, China
}

From the seeds of Acacia confusa, a chitinase-like antifungal protein designated as acaconin that demonstrated antifungal activity toward Rhizoctonia solani with an $\mathrm{IC}_{50}$ of $30 \pm 4 \mu \mathrm{M}$ was isolated. Acaconin demonstrated an $\mathrm{N}$-terminal sequence with pronounced similarity to chitinases and a molecular mass of $32 \mathrm{kDa}$. It was isolated by chromatography on Q-Sepharose, SP-Sepharose and Superdex 75 and was not bound by either ion exchanger. Acaconin was devoid of chitinase activity. The antifungal activity against Rhizoctonia solani was completely preserved from $\mathrm{pH} 4$ to 10 and from $0^{\circ} \mathrm{C}$ to $70^{\circ} \mathrm{C}$. Congo Red staining at the tips of $R$. solani hyphae indicated inhibition of fungal growth. However, there was no antifungal activity toward Mycosphaerella arachidicola, Fusarium oxysporum, Helminthosporium maydis, and Valsa mali. Acaconin inhibited proliferation of breast cancer MCF-7 cells with an IC ${ }_{50}$ of $128 \pm 9 \mu \mathrm{M}$ but did not affect hepatoma HepG2 cells. Its IC I $_{50}$ value toward HIV-1 reverse transcriptase was $10 \pm 2.3 \mu \mathrm{M}$. The unique features of acaconin include relatively high stability when exposed to changes in ambient $\mathrm{pH}$ and temperature, specific antifungal and antitumor actions, potent HIVreverse transcriptase inhibitory activity, and lack of binding by strongly cationic and anionic exchangers.

Keywords: antifungal protein, antitumor, anti-HIV-1 reverse transcriptase, Acacia confusa

Received: 15 October, 2009; revised: 09 June, 2010; accepted: 08 July, 2010; available on-line: 19 August, 2010

\section{INTRODUCTION}

The seeds of flowering plants contain an abundance of proteins, some of which are storage proteins but may also play a role of protection from pathogenic microbes and phytophagous insects. Antifungal proteins (Patil et al., 2009), antiviral proteins, lectins/hemagglutinins, ribosome-inactivating proteins, proteinase inhibitors, arcelins, and $\alpha$-amylase inhibitors are some examples of the myriad of seed proteins. The aforementioned proteins are collectively called defense proteins in view of their antipathogenic activities.

Chitinase is one kind of antifungal proteins. It has been purified from different organisms including algae (Shirota et al., 2008), fungi (Nguyen et al., 2008; 2009), including plant seeds (Patil et al., 2009), bacteria (Liu et al., 2009), insects (Genta et al., 2006), including silkworms (Kabir et al., 2006), amphibians (Oshima et al., 2002), fish (Ikeda et al., 2009), etc.
Research on antifungal proteins has intensified in recent years. Transgenic crops expressing genes encoding antifungal proteins are expected to have augmented resistance against pathogenic fungi. There are various types of antifungal proteins with distinctly different amino-acid sequences. They include thaumatin-like proteins (Chua et al., 2007), chitinases (Patil et al., 2009), glucanases (Buchner et al., 2002), ribosome-inactivating proteins, lipid transfer proteins (Choi et al., 2008) and others. The intent of the present study was to isolate and characterize an antifungal protein from fresh Acacia confusa seeds, and to compare its characteristics and activities with previously reported antifungal proteins. Such information would enrich the scarce literature data that is currently available about $A$. confusa.

\section{MATERIALS AND METHODS}

Purification of acaconin. Seeds were collected from Acacia confusa trees. The seeds have been authenticated by Professor Shiuying Hu, Honorary Professor of Chinese Medicine, The Chinese University of Hong Kong, and deposited with the voucher number NG2009023 in Lab 302, Basic Medical Science Building, The Chinese University of Hong Kong. The seeds $(150 \mathrm{~g})$ were first extracted with distilled water using a Waring blender. The extract obtained after centrifugation of the slurry was saved. $\mathrm{NH}_{4} \mathrm{HCO}_{3}$ buffer $(1 \mathrm{M}, \mathrm{pH} 8.8)$ was then added to the extract to $10 \mathrm{mM}$. The extract was then loaded on a $5 \mathrm{~cm} \times 13 \mathrm{~cm}$ column of Q-Sepharose (GE Healthcare), unadsorbed proteins were eluted with 10 $\mathrm{mM} \mathrm{NH} \mathrm{HCO}_{3}$ buffer ( $\mathrm{pH}$ 8.8) while adsorbed proteins were desorbed by stepwise addition of $1 \mathrm{M} \mathrm{NaCl}$ in the starting buffer. The unadsorbed fraction was subsequently fractionated on SP-Sepharose after dialysis against 10 $\mathrm{mM} \mathrm{NH} \mathrm{OAc}_{4}$ buffer ( $\mathrm{pH} 4.5$ ), adsorbed proteins were desorbed with the $\mathrm{NH}_{4} \mathrm{OAc}$ buffer containing $1 \mathrm{M}$ $\mathrm{NaCl}$. The unadsorbed fraction was then lyophylized and subjected to gel filtration in $10 \mathrm{mM} \mathrm{NH}_{4} \mathrm{HCO}_{3}$ buffer $(\mathrm{pH}$ 8.8) on a Superdex 75 HR $10 / 30$ column by fast protein liquid chromatography using AKTA purifier (GE Healthcare). The third peak (S3) represented purified antifungal protein designated as acaconin.

Molecular mass determination using SDS/PAGE gel filtration, and $\mathrm{N}$-terminal amino acid sequencing. Purified acaconin was analyzed by SDS/PAGE

e-mail: Sze Kwan Lam: lamszekwan@yahoo.com.hk; Tzi Bun Ng: b021770@mailserv.cuhk.edu.hk

Abbreviations: MTT, Thiazolyl Blue Tetrazolium; SDS/PAGE, sodium dodecyl sulphate/polyacrylamide gel electrophoresis 
(Laemmli \& Farve, 1973). Gel filtration on a fast protein liquid chromatography Superdex 75 column HR 10/30 (GE Healthcare) by employing an AKTA Purifier (GE Healthcare) was performed to ascertain the molecular mass of the antifungal protein. The column had previously been calibrated with molecular mass markers, including Blue Dextran 2000 (to determine void volume), bovine serum albumin $(67 \mathrm{kDa})$, ovalbumin (43 kDa), chymotrypsinogen A $(25 \mathrm{kDa})$, myoglobulin $(17.6 \mathrm{kDa})$, ribonuclease $\mathrm{A}(13.7 \mathrm{kDa})$, aprotinin $(6.5 \mathrm{kDa})$ and vitamin B12 (1.3 kDa) (GE Healthcare). The N-terminal sequence of acaconin was determined as described in reference (Lam et al., 2009), using a Hewlett-Packard sequencer.

Protein determination. The protein concentration was determined by Bradford reagent (dye-binding method) using bovine serum albumin as standard.

Determination of chitinase activity. Acid-swollen chitin was prepared by adding $0.5 \mathrm{~g}$ of chitin to $50 \mathrm{ml}$ of dilute aqueous acetic acid $(\mathrm{pH} 2.5)$ and stirring the mixture for $72 \mathrm{~h}$ at $4{ }^{\circ} \mathrm{C}$. The $\mathrm{pH}$ of the suspension was adjusted to 5.0 by adding $2 \mathrm{M} \mathrm{NaOH}$ (Pegg, 1998). The assay of chitinase activity was performed by incubating swollen chitin in $50 \mathrm{mM}$ ammonium acetate $(\mathrm{pH} 5.5)$ at $37^{\circ} \mathrm{C}$ for half hour. One unit of enzyme activity using chitin as substrate is defined as the amount of enzyme required to form $30 \mathrm{nmol}$ of $N$-acetylglucosamine per 30 min. The amount of reducing sugar was estimated by using dinitrosalicyclic acid (Miller, 1959).

Assay of antifungal activity. The various chromatographic fractions were monitored for antifungal activity by agar diffusion assay using a $90 \mathrm{~mm} \times 15 \mathrm{~mm}$ petri dish containing $10 \mathrm{ml}$ of potato dextrose agar. A small amount of fungus was inoculated in the center of Petri dish. After the mycelial colony had developed on the agar, at a distance of $1 \mathrm{~cm}$ away from the rim of the colony were placed sterile blank paper disks $(0.625$ $\mathrm{cm}$ in diameter). The samples were applied to the disks. The plates were incubated at $25^{\circ} \mathrm{C}$ until mycelial growth from the center of disk had enveloped peripheral disks containing the control and formed crescents of inhibition around the paper disks with samples possessing antifungal activity. The pathogenic fungi species used included Mycosphaerella arachidicola, Fusarium oxysporum, Helminthosporium maydis, Valsa mali and Rhizoctonia solani (Lam \& Ng, 2009). Nystatin (Sigma) was used as a positive control.

To determine the $\mathrm{IC}_{50}$ value, different concentrations of acaconin were added separately to aliquots, each containing $2 \mathrm{ml}$ of potato dextrose agar at $45^{\circ} \mathrm{C}$, mixed rapidly, and poured into separate $3.3-\mathrm{cm}$ Petri dishes. After the agar had cooled down, a small amount of mycelia was inoculated. Buffer only served as a negative control. The dishes were incubated at $25^{\circ} \mathrm{C}$ for 3 days, the area of the mycelial colony was measured and the $\mathrm{IC}_{50}$ value for the antifungal activity of acaconin against $R$. solani was determined ( $\mathrm{Lam} \& \mathrm{Ng}, 2009)$. $\mathrm{IC}_{50}$ is the concentration of the antifungal protein required to produce $50 \%$ reduction of the area of mycelial colony.

To test the effect of different $\mathrm{pH}$ and temperature on the antifungal activity of acaconin against $R$. solani, the protein was incubated at various $\mathrm{pH}$ values and temperatures for $15 \mathrm{~min}$. The $\mathrm{pH}$ was restored to 7 and the thermal treatment stopped by instant placing in ice before the assay of antifungal activity was carried out.

Assay of growth inhibition at hyphal tips. This assay was conducted to observe growth inhibition at hyphal tips of $R$. solani. Following incubation of $R$. solani with acaconin for $4 \mathrm{~h}$, Congo Red was added to a final concentration of $1 \mathrm{mM}$. Fluorescence was examined $2 \mathrm{~h}$ later by fluorescence microscopy using an excitation wavelength of $543 \mathrm{~nm}$ and an emission wavelength of $560-635 \mathrm{~nm}$. The staining condition of growing hyphae was observed (Moreno et al., 2006).

Assay of HIV-1 reverse transcriptase inhibitory activity. An enzyme-linked immunosorbent assay kit from Boehringer Mannheim was used to assay acaconin for the ability to inhibit HIV-1 reverse transcriptase (Zhang et al., 2009). Brassica campestris lipid transfer protein (Lin et al., 2007) was used as a positive control.

Assay of cytotoxic activity. The assay of the cytotoxic activity of the isolated acaconin was carried out on human hepatoma HepG2 cells and human breast cancer MCF-7 cells (Lam \& Ng, 2009). The cells were cultured in RPMI-1640 medium supplemented with $10 \%$ fetal calf serum and $1 \%$ penicillin-streptomycin, in a humidified atmosphere of $5 \% \mathrm{CO}_{2}$ at $37^{\circ} \mathrm{C}$. The cells $(5000$ cells/100 $\mu \mathrm{l}$ per well) were seeded in a 96-well culture plate and serial dilutions of a solution of acaconin or doxorubicin (as the positive control) in $100 \mu \mathrm{l}$ medium were added. A solution of medium only was added as the negative control. After incubation for $48 \mathrm{~h}$, the cells were harvested, standard MTT assay was performed to determine the level of its inhibitory activity. All reported values are means of triplicate samples.

\section{RESULTS}

\section{Isolation of antifungal protein}

Seeds (150 g) collected from $A$. confusa trees were homogenized in 1 liter of $10 \mathrm{mM} \mathrm{NH}_{4} \mathrm{HCO}_{3}$ buffer $(\mathrm{pH}$ 8.8). The homogenate was centrifuged and the supernatant collected. Ion exchange chromatography of the seed extract on Q-Sepharose yielded a large unadsorbed fraction (Q1) and one adsorbed fraction (Q2) desorbed with $1 \mathrm{M} \mathrm{NaCl}$ (Fig. 1A). The unadsorbed fraction Q1 was resolved on SP-Sepharose into an unadsorbed fraction (SP1) and an adsorbed fraction (SP2) of similar size eluted with $1 \mathrm{M} \mathrm{NaCl}$ (Fig. 1B). SP1 was then chromatographed on Superdex 75. Five fractions, S1 to S5, were obtained (Fig. 1C). The antifungal activity resided in fraction S3. Fraction S3 was re-chromatographed on Superdex 75 and was eluted as a single homogeneous peak with the same elution volume as before corresponding to a molecular mass of $32 \mathrm{kDa}$ (not shown). It demonstrated a single 32-kDa band in SDS/PAGE (Fig. 2). The purified chitinase was designated as acaconin. A summary of the purification of acaconin is included in Table 1. The N-terminal sequence of acaconin was homologous to those of other chitinases (Table 2).

\section{Biological activities of isolated antifungal protein}

Acaconin was deficient in chitinase activity when tested up to $100 \mu \mathrm{M}$. It inhibited mycelial growth of $R$. solani in a dose-dependent manner with an $\mathrm{IC}_{50}$ of $3 \pm 4 \mu \mathrm{M}$ (Fig. 3) but not of $M$. arachidicola, $H$. maydis, F. oxysporum, and $V$. mali when tested with $50 \mu \mathrm{g}(10 \mu \mathrm{l}$ of $5 \mathrm{mg} / \mathrm{ml}$ acaconin solution was added) in agar diffusion assay (not shown). The antifungal activity of acaconin was stable throughout the $\mathrm{pH}$ range $4-10$. Only $50 \%$ of the antifungal activity remained at $\mathrm{pH} 3$ and 11 . It was deactivated at $\mathrm{pH} 0-2$ or 12-14. It was stable in the temperature range $0{ }^{\circ} \mathrm{C}-70{ }^{\circ} \mathrm{C}$. Only $55 \%$ of antifungal activity remained at $80^{\circ} \mathrm{C}$. It was lost above $90^{\circ} \mathrm{C}$. 

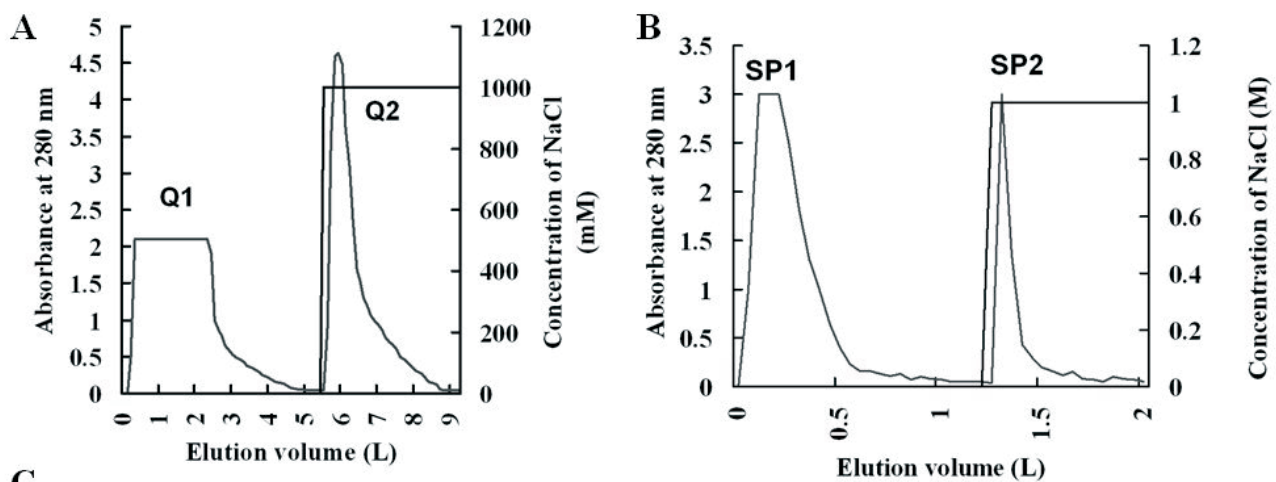

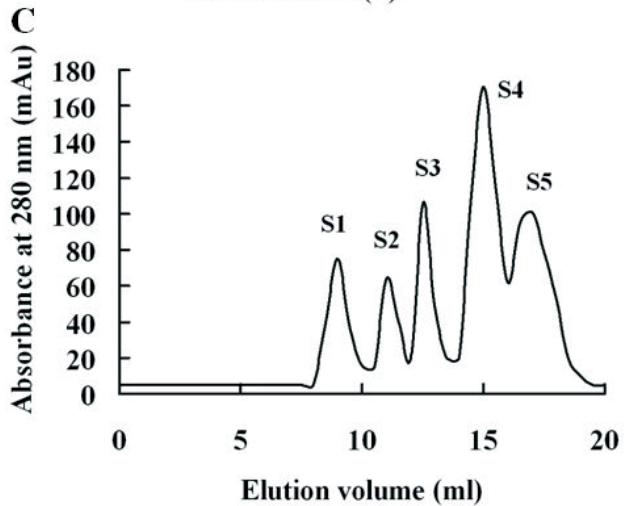

Elution volume (ml)
Figure 1. Purification of acaconin

(A) Ion exchange chromatography of Acacia confusa extract on Q-Sepharose. Antifungal activity was confined to the unbound fraction Q1. (B) lon exchange chromatography of fraction Q1 on SP-Sepharose. Antifungal activity was found in the unbound fraction SP1. (C) Size exclusion chromatography of SP1 fraction on Superdex 75. Fraction S3 represents acaconin.

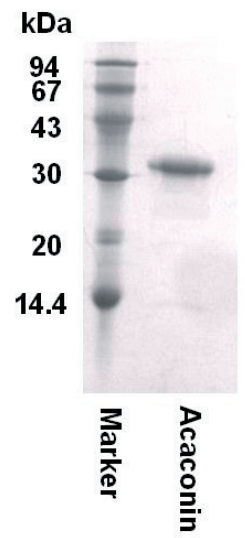

Hyphal growth in R. solani was impeded, as evidenced by stainable with Congo Red at the hyphal tip (Fig. 4). It inhibited proliferation of MCF-7 tumor cells with an $\mathrm{IC}_{50}$ of $128 \pm 9 \mu \mathrm{M}$ (Fig. 5), but there was no inhibition against HepG2 cells. It inhibited HIV-1 reverse transcriptase with an $\mathrm{IC}_{50}$ of $10 \pm 2.3 \mu \mathrm{M}$ (Fig. 6).

Table 1. Yields of various active chromatographic fractions obtained at different stages of purification

\begin{tabular}{llcc}
\hline Column & $\begin{array}{l}\text { Chromatographic } \\
\text { fraction }\end{array}$ & Yield (mg) & Yield (\%) \\
\hline \multirow{2}{*}{ Q-Sepharose } & Crude extract & 1200 & 100 \\
SP-Sepharose & SP1 & 253 & 21.1 \\
Superdex 75 & S3 (acaconin) & 128 & 10.6 \\
\hline
\end{tabular}

*From $150 \mathrm{~g}$ seeds

\section{DISCUSSION}

Acaconin is an antifungal protein with an N-terminal sequence highly homologous to chitinases. The N-terminal sequence of acaconin is homologous to those of other chitinases, but it does not possess a chitinase activity. Acaconin is similar to chitinase-like antifungal proteins from emperor banana fruits (Ho \& Ng, 2007), and black turtle bean (Chu \& Ng, 2005) in demonstrating an $\mathrm{N}$ terminal sequence with homology to chitinases. In this context, it is reminiscent of the observation that passiflin possesses a $\beta$-lactoglobulin-like $\mathrm{N}$-terminal sequence but does not cross-react with an anti- $\beta$-lactoglobulin antiserum. Passiflin shows antifungal activity and cytotoxicity which are absent in $\beta$-lactoglobulin. Passiflin is immunologically and biologically unrelated to $\beta$-lactoglobulin (Lam \& Ng, 2009). Similarly, thaumatin-like proteins have antifungal activity but no sweet taste while the converse is true of thaumatin although they are highly homologous in structure (Ye et al., 1999).

Chitinases have a variety of molecular masses. The molecular mass of small chitinases, e.g. Panax notoginseng chitinase (Lam \& Ng, 2001), is as low as $15 \mathrm{kDa}$. The molecular masses of some chitinases are higher, e.g. that of Oreochromis niloticus chitinase (Molinari et al., 2007) and Bombyx mori chitinase (Kabir et al., 2006) is $75 \mathrm{kDa}$. The range of molecular masses of most chitinases is from 30 $\mathrm{kDa}$ to $60 \mathrm{kDa}$ (Patil et al., 2009; Liu et al., 2009; Ikeda et al., 2009). The molecular mass of acaconin $(32 \mathrm{kDa})$ is within the range reported for chitinases.

The chromatographic behavior of acaconin is distinct from that of antifungal proteins in general. Most of the chitinases are adsorbed on anion exchangers. Aeromonas schubertii chitinases (Liu et al., 2009) are adsorbed on DEAE-Sepharose and Mono Q. Some are adsorbed on cation exchangers, e.g. emperor banana chitinase (Ho \& $\mathrm{Ng}, 2007)$. Some are adsorbed on both kinds of ion exchangers, e.g. Bacillus cereus chitinase (Wang et al., 2009). 
Table 2. N-terminal amino-acid sequence of acaconin in comparison with counterparts from other species

\begin{tabular}{llll}
\hline & Residue No. & N-terminal sequence & Homology (\%) \\
\hline A. confusa chitinase & 1 & EQHGRQAGGALCMGG & - \\
Phaseolus vulgaris class I chitinase & 1 & $\underline{\text { EQGRQAGGALCPGG }}$ & 87 \\
Vitis vinifera chitinase & 23 & $\underline{\text { EQCGRQAGGALCSGG }}$ & 87 \\
Euonymus europaeus chitinase & 20 & $\underline{\text { EQCGRQAGGALCPGG }}$ & 87 \\
Hevea brasiliensis class I chitinase & 1 & $\underline{\text { EQCGRQAGGALCPGG }}$ & 87 \\
\hline
\end{tabular}

Identical amino-acid residues are underscored

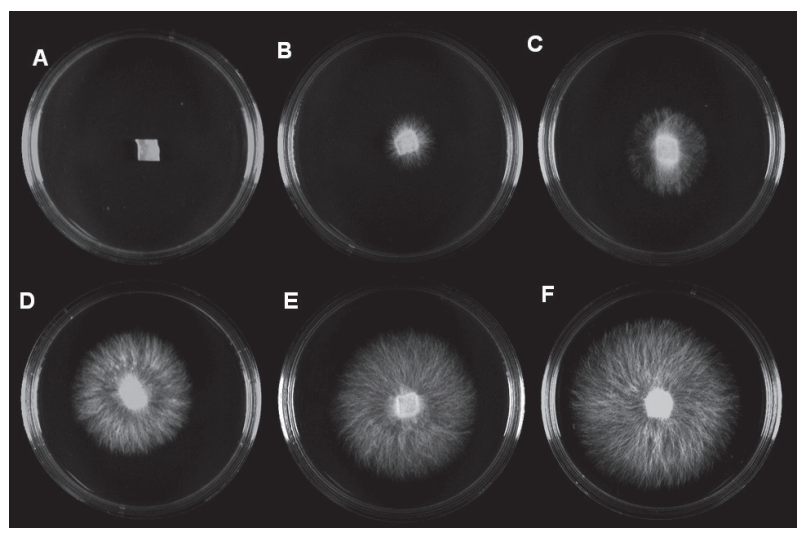

Figure 3. Antifungal activity of acaconin toward Rhizoctonia solani

(A) $100 \mu \mathrm{M}$ acaconin, (B) $75 \mu \mathrm{M}$ acaconin, (C) $50 \mu \mathrm{M}$ acaconin, (D) $25 \mu \mathrm{M}$ acaconin, (E) $12.5 \mu \mathrm{M}$ acaconin, (F) buffer control. The IC was $27 \pm 3 \mu \mathrm{M}$ (mean \pm S.D., $n=3$ ). Results shown here are from one of the three experiments.

In some cases, the chitinase was purified by affinity chromatography, e.g. Tamarindus indica chitinase (Rao \& Gowda, 2008). Acaconin is unadsorbed on Q-Sepharose (anion exchanger) and SP-Sepharose (cationic exchangers), in contrast to other chitinases.

Not all chitinases have antifungal activity. Some chitinases can inhibit the growth of a number of fungi. $P$. notogingseng chitinase exerts antifungal activity against Coprinus comatus, F. oxysporum and $M$. arachidicola (Lam \& Ng, 2001). Black turtle bean chitinase specifically inhibits $F$. oxysporum and $M$. arachidicola (Chu \& Ng, 2005). Mung bean chitinase inhibits Fusarium solani, F. oxysporum, M. arachidicola, Pythium aphanidermatum, and Sclerotium rolfsii (Wang et al., 2005). Acaconin exhibits specific antifungal activity towards $R$. solani but not to a number of other fungal
A1

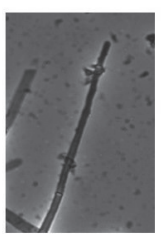

A2

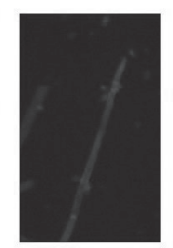

B1

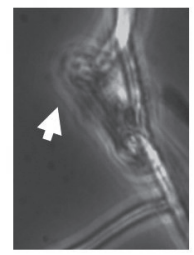

B2

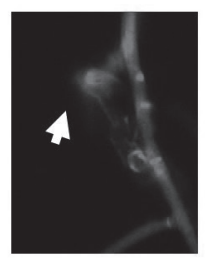

Figure 4. Congo Red staining showing growth inhibition at hyphal tips of $R$. solani

(A) Buffer control. Pictures A1 and A2 were taken under light microscope and fluorescence microscope, respectively. (B) Treatment with $50 \mu \mathrm{M}$ acaconin. Pictures B1 and B2 taken under light microscope and fluorescence microscope, respectively. Hyphal tips were stained with Congo Red (white arrow) showing that the growth was inhibited. species such as $M$. arachidicola, H. maydis, F. oxysporum, and $V$. mali. The specificity of the antifungal action of acaconin is similar to that of some chitinases listed below. Ananas comosus chitinase can inhibit Trichoderma viride (Taira et al., 2005). Emperor banana chitinases inhibit mycelial growth in F. oxysporum (Ho \& Ng, 2007). Trichoderma aureoviride DY-59 and Rhizopus microsporus VS-9 chitinases inhibit the growth of F. solani (Nguyen et al., 2008).

Acaconin demonstrates a relatively high $\mathrm{pH}$ stability from $\mathrm{pH} 4$ to $\mathrm{pH} 10$, which is higher than that reported for some chitinases (Kabir et al., 2006). Bacillus licheniformis $\mathrm{SK}-1$ chitinase is more stable (from $\mathrm{pH} 4$ to $\mathrm{pH}$ 9) than other chitinases (Kudan \& Pichyangkura, 2009), in which it is similar to acaconin. Some antifungal proteins have not been tested for $\mathrm{pH}$ stability (Morre et al., 2004). However, acaconin is similar to other chitinases in thermostability (Wang et al., 2008).

To the best of our knowledge, very few chitinases have been reported to have cytotoxicity toward mammalian cells. Serratia marcescens and Streptomyces griseus chitinases show potent cytotoxicity toward cancer cells (breast cancer MCF-7 cells) (Pan et al., 2005). Acaconin manifests a specific antitumor action against MCF-7 cells $\left(\mathrm{IC}_{50}=128 \mu \mathrm{M}\right)$ but not against hepatoma HepG2 cells. The cytotoxic potency of acaconin is similar to that of Allium tuberosum chitinase (Lam et al., 2000).

Only a few chitinases show HIV-1 reverse transcriptase inhibitory activity. Acaconin has a highly potent inhibitory action $\left(\mathrm{IC}_{50}=10 \mu \mathrm{M}\right)$ against HIV-1 reverse transcriptase, with a similar potency to chestnut chitinase (Wang \& Ng, 2003). Pinto bean chitinase (Ye \& $\mathrm{Ng}, 2003$ ), Delandia umbellata chitinase (Ye \& Ng, 2002) and Allium tuberosum chitinase (Lam et al., 2000) show a much weaker inhibitory potency toward HIV-1 reverse transcriptase, while mung bean chitinase lacks such activity (Lin et al., 2007).

Chitinases act on chitin in the fungal cell wall to exert their antifungal activity. The antifungal activity of chitinases is directly correlated with the proportion of chitin in the fungal cell wall (Yan et al., 2008). Congo Red, a dye that binds strongly to $\beta$-glucans, is used to stain the fungal cell wall. A strong Congo Red signal was detected at the site where acaconin attacks the fungal cell wall. The hyphae are probably damaged by acaconin causing accumulation of chitin and so inhibition of hyphal growth. Similarly, the hyphal tips of rice blast fungus Magnaporthe grisea are stained by Congo Red after treatment with Aspergillus giganteus antifungal protein (Moreno et al., 2006).

Phytochemicals with a small molecular mass have been identified in the flowers (Wu et al., 2008b), leaves (Lee et al., 2000), heartwood (Wu et al., 2008a) and bark (Tung et al., 2009) of $A$. confusa. However, there is a dearth of information pertaining to their protein constituents. Only a trypsin inhibitor (Lin et al., 1991) has been purified from seeds. Hence, the present report of an antifungal protein from $A$. confusa seeds adds to the scanty literature.

The novel aspects of the isolated chitinase include unique chromatographic behavior on cation and anion exchangers, relatively high thermostability and $\mathrm{pH}$ stabil- 


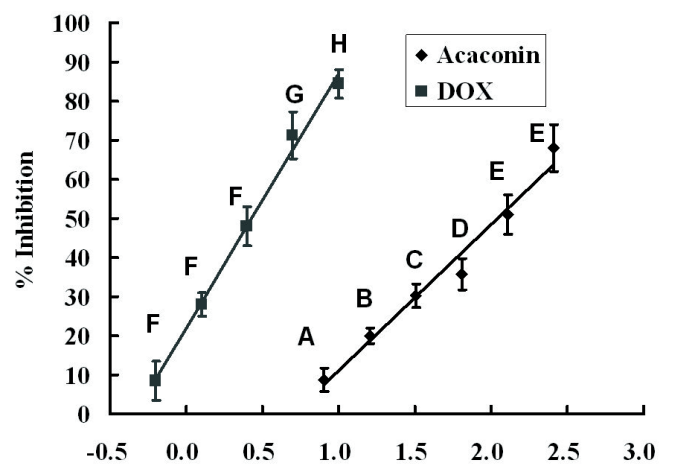

$\log$ concentration of acaconin/doxorubicin $(\mu \mathrm{M})$

\section{Figure 5. Effects of acaconin on viability of breast cancer MCF-7} cells

The viability of MCF-7 cells after incubation for $48 \mathrm{~h}$ in the presence of various concentrations of acaconin was determined as described in Materials and Methods. Viability of cells in RPMI medium only was taken as $100 \%$. Values are expressed as mean \pm S.D. $(n=3)$. Data points marked with different letters $(A, B, C, D$ and $E)$ are significantly different $(P<0.05)$ from one another when analyzed by ANOVA followed by Duncan's multiple range test. The $I_{50}$ was $128 \pm 9 \mu \mathrm{M}$ (mean \pm S.D., $\mathrm{n}=3$ ). Results shown here are from one of the three experiments.

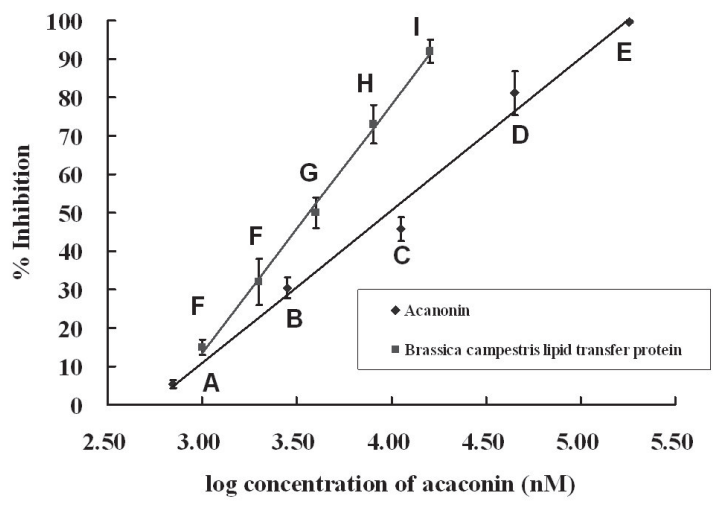

Figure 6. Dose-dependent inhibitory effect of acaconin on HIV-1 reverse transcriptase

Data are represented as the mean \pm S.D. $(n=3)$. Data points marked with different letters $(A, B, C$, and $D)$ are significantly different $(P<0.05)$ from one another when analyzed by ANOVA followed by Duncan's multiple range test. The $\mathrm{IC}_{50}$ was $10 \pm 2.3 \mu \mathrm{M}$ (mean \pm S.D., $n=3$ ). Results shown here are from one of the three experiments.

ity and specificity of antifungal action toward $\mathrm{R}$. solani and absence of activity toward a number of other fungi, specificity of cytotoxicity toward breast cancer cells and lack of activity toward hepatoma cells, and highly potent inhibitory activity against HIV-1 reverse transcriptase.

\section{REFERENCES}

Buchner P, Rochat C, Wuillème S, Boutin JP (2002) Characterization of a tissue-specific and developmentally regulated $\beta-1,3$-glucanase gene in pea (Pisum sativum). Plant Mol Biol 49: 171-186.

Choi AM, Lee SB, Cho SH, Hwang I, Hur CG, Suh MC (2008) Isolation and characterization of multiple abundant lipid transfer protein isoforms in developing sesame (Sesamum indicum L.) seeds. Plant Physiol Biochem 46: 127-139.

Chu KT, Ng TB (2005) Purification and characterization of a chitinaselike antifungal protein from black turtle bean with stimulatory effect on nitric oxide production by macrophages. Biol Chem 386: 19-24.
Chua AC, Chou WM, Chyan CL, Tzen JT (2007) Purification, cloning, and identification of two thaumatin-like protein isoforms in jelly fig (Ficus awkeotsang) Achenes. J Agric Food Chem 55: 7602-7608.

Colussi PA, Specht CA, Taron CH (2005) Characterization of a nucleus-encoded chitinase from the yeast Kluyveromyces lactis. Appl Environ Microbiol 71: 2862-2869.

Genta FA, Blanes L, Cristofoletti PT, do Lago CL, Terra WR, Ferreira C (2006) Purification, characterization and molecular cloning of the major chitinase from Tenebrio molitor larval midgut. Insect Biochem Mol Biol 36: 789-800.

Ho VS, Ng TB (2007) Chitinase-like proteins with antifungal activity from emperor banana fruits. Protein Pept Lett 14: 828-831.

Ikeda M, Miyauchi K, Mochizuki A, Matsumiya M (2009) Purification and characterization of chitinase from the stomach of silver croaker Pennahia argentatus. Protein Expr Purif 65: 214-222

Kabir KE, Hirowatari D, Watanabe K, Koga D (2006) Purification and characterization of a novel isozyme of chitinase from Bombyx mori. Biosci Biotechnol Biochem 70: 252-262.

Kudan S, Pichyangkura R (2009) Purification and characterization of thermostable chitinase from Bacillus licheniformis SK-1. Appl Biochem Biotechnol 157: 23-35.

Laemmli UK, Farve M (1973) Maturation of the head of bacteriophage T4. I. DNA packaging events. J Mol Biol 80: 575-599.

Lam SK, Ng TB (2001) Isolation of a small chitinase-like antifungal protein from Panax notoginseng (sanchi ginseng) roots. Int I Biochem Cell Biol 33: 287-292.

Lam SK, Ng TB (2009) Passiflin, a novel dimeric antifungal protein from seeds of the passion fruit, Phytomedicine 16: 172-180.

Lam SK, Han QF, Ng TB (2009) Isolation and characterization of a lectin with potentially exploitable activities from caper (Capparis spinosa) seeds. Biosci Rep 29: 293-299.

Lam YW, Wang HX, Ng TB (2000) A robust cysteine-deficient chitinase-like antifungal protein from inner shoots of the edible chive Allium tuberosum. Biochem Biophys Res Commun 279: 74-80.

Lee TH, Qiu F, Waller GR, Chou CH (2000) Three new flavonol galloylglycosides from leaves of Acacia confusa. I Nat Prod 63: 710-712.

Lin JY, Chu SC, Wu HC, Hsieh YS (1991) Trypsin inhibitor from the seeds of Acacia confusa. I Biochem 110: 879-883

Lin P, Xia X, Wong JH, Ng TB, Ye XY, Wang S, Shi X (2007) Lipid transfer proteins from Brassica campestris and mung bean surpass mung bean chitinase in exploitability. J Peptide Sci 18: 642-648.

Liu CL, Shen CR, Hsu FF, Chen JK, Wu PT, Guo SH, Lee WC, Yu FW, Mackey ZB, Turk J, Gross ML (2009) Isolation and identification of two novel SDS-resistant secreted chitinases from Aeromonas schubertii. Biotechnol Prog 25: 124-131.

Miller GL (1959) Use of dinitrosalicylic acid reagent for determination of reducing sugar. Anal Chem 31: 426-428.

Molinari LM, Pedroso RB, Scoaris D de O, Ueda-Nakamura T, Nakamura CV, Dias Filho BP (2007) Identification and partial characterisation of a chitinase from Nile tilapia, Oreochromis niloticus. Comp Biochem Physiol B Biochem Mol Biol 149: 81-87.

Moore KG, Price MS, Boston RS (2004) Weissinger, A-K., and Payne, G-A.: A Chitinase from Tex6 Maize Kernels Inhibits Growth of Aspergillus flavus. Phytopathology 94: 82-87.

Moreno AB, Martinez Del Pozo A, San Segundo B (2006) Biotechnologically relevant enzymes and proteins. Antifungal mechanism of the Aspergillus giganteus AFP against the rice blast fungus Magnaporthe grisea. Appl Microbiol Biotechnol 72: 883-895.

Nguyen NV, Kim YJ, Oh KT, Jung WJ, Park RD (2008) Antifungal activity of chitinases from Trichoderma aureoviride DY-59 and Rhiropus microsporus VS-9. Curr Microbiol 56: 28-32.

Nguyen VN, Oh IJ, Kim YJ, Kim KY, Kim YC, Park RD (2009) Purification and characterization of chitinases from Paecilomyces variotii DG-3 parasitizing on Meloidogyne incognita eggs. I Ind Microbiol Biotechnol 36: 195-203.

Oshima H, Miyazaki R, Ohe Y, Hayashi H, Kawamura K, Kikuyama S (2002) Isolation and sequence of a novel amphibian pancreatic chitinase. Comp Biochem Physiol B Biochem Mol Biol 132: 381-388.

Pan XQ, Shih CC, Harday J (2005) Chitinase induces lysis of MCF7 cells in culture and of human breast cancer xenograft B11-2 in SCID mice. Anticancer Res 25: 3167-3172.

Patil DN, Datta M, Chaudhary A, Tomar S, Sharma AK, Kumar P (2009) Isolation, purification, crystallization and preliminary crystallographic studies of chitinase from tamarind (Tamarindus indica) seeds. Acta Crystallogr Sect F Struct Biol Cryst Commun 65: 343-345.

Pegg GF (1998) Chitinase from Verticillium albo-atrum. Methods Enzymol 161: 474-489.

Rao DH, Gowda LR (2008) Abundant class III acidic chitinase homologue in tamarind (Tamarindus indica) seed serves as the major storage protein. I Agric Food Chem 56: 2175-2182.

Shirota K, Sato T, Sekiguchi J, Miyauchi K, Mochizuki A, Matsumiya M (2008) Purification and characterization of chitinase isozymes from a red algae, Chondrus verrucosus. Biosci Biotechnol Biochem 72: 3091-3099. 
Taira T, Toma N, Ishihara M (2005) Purification, characterization, and antifungal activity of chitinases from pineapple (Ananas comosus) leaf. Biosci Biotechnol Biochem 69: 189-196.

Tung YT, Wu JH, Huang CC, Peng HC, Chen YL, Yang SC, Chang ST (2009) Protective effect of Acacia confusa bark extract and its active compound gallic acid against carbon tetrachloride-induced chronic liver injury in rats. Food Chem Toxicol 47: 1385-1392.

Wang HX, Ng TB (2003) Purification of castamollin, a novel antifungal protein from Chinese chestnuts. Protein Expr Purif 32: 44-51.

Wang S, Wu J, Rao P, Ng TB, Ye X (2005) A chitinase with antifungal activity from the mung bean. Protein Expr Purif 40: 230-236.

Wang SY, Zhou JJ, Shao B, Lu YJ, Rao PF (2008) A thermostable chitinase with chitin-binding activity from Phaseolus limensis. J Food Sci 76: 452-457.

Wang SL, Chao CH, Liang TW, Chen CC (2009) Purification and characterization of protease and chitinase from Bacillus cereus TKU006 and conversion of marine wastes by these enzymes. Mar Biotechnol NY) 11: 334-344.

Wu JH, Huang CY, Tung YT, Chang ST (2008a) Online RP-HPLCDPPH screening method for detection of radical-scavenging phytochemicals from flowers of Acacia confusa. I Agric Food Chem 56: 328-332.
Wu JH, Tung YT, Chien SC, Wang SY, Kuo YH, Shyur LF, Chang ST (2008b) Effect of phytocompounds from the heartwood of Acacia confusa on inflammatory mediator production. I Agric Food Chem 56: 1567-1573.

Yan R, Hou J, Ding D, Guan W, Wang C, Wu Z, Li M (2008) In vitro antifungal activity and mechanism of action of chitinase against four plant pathogenic fungi. I Basic Microbiol 48: 293-301.

Ye XY, Ng TB (2002) Delandin, a chitinase-like protein with antifungal, HIV-1 reverse transcriptase inhibitory and mitogenic activities from the rice bean Delandia umbellate. Protein Expr Purif 24: 524-529.

Ye XY, Ng TB (2003) Isolation of vulgin, a new antifungal polypeptide with mitogenic activity from the pinto bean. I Pept Sci 6: 114-119.

Ye XY, Wang HX, Ng TB (1999) First chromatographic isolation of an antifungal thaumatin-like protein from French bean legumes and demonstration of its antifungal activity. Biochem Biophys Res Commun 263: $130-134$.

Zhang GQ, Sun J, Wang HX, Ng TB (2009) A novel lectin with antiproliferative activity from the medicinal mushroom Pholiota adiposa. Acta Biochim Pol 56: 415-421. 